Baths are used as a medicine and a luxury by the Egyptians. The traveller, Stephens, after bathing at Minyeh, says, 'Ileft the bath a different man; all my moral and physical strength was roused, and I no longer drooped or looked back." ("Incidents of Travel in Egypt \&c.") Most nations, civilized and savage, have their bathing establishments. "Through all Finland," says Dr. Davy, "Lapland, Norway, and the vast northern empire, there is no hut so destitute as not to possess its family vapour-bath, whither the family resort every Saturday, at least, and every day in case of sickness." The Indians of North and South America employ the vapour-bath in all cases of illness. (See Uloa and Catlin.) The Hon. Basil Coclurane, on his return from India, had a severe illness relieved or cured by the vapour-bath; and so impressed was he with the benefits of bathing generally, that he had an establishment at his residence, Portman-square, for the use of the sick poor. In favour of the efficacy of these baths, the faculty gave a testimonial, affixed to which were the names of nearly a hundred of the most eminent medical men, including Mr. Chine, Dr. Hooper, Sir Martin Tupper, Dr. Farre, Sir Astley Cooper, Dr. Carpue, Sir Charles Bell.

From the foregoing sketch, it will easily be perceived that the medical profession has preserved and employed, amongst other remedies, that brought forward by Dr. Macleod, for above 2000 years. Concluding that the whole of Dr. Macleod's febrifuge consists in diaphoresis, and premising that cold water, when used with this intention, either by affusion, bathing, sponging, or the application of cold sheets, is much the same, except that the latter is the most imperfect modification of the remedy, we leave to the Doctor the delicate task of deciding what is the relative value of a diaphoresis by each, to a good sweating by a scruple of Dover's powder.

Supposing the Doctor's plan was worth a trial, it is highly impracticable. The people who suffer from fever are generally of the poorest class, and would consequently come under the care of the Union surgeons. Supposing one of these hardworked gentlemen had twenty fever cases, scattered over a circumference of twenty miles, I ask, how is he to administer the cold.sheet remedy to one half of them, especially if the sheet requires renewing every ten minntes, which the Doctor says is very probable? I anticipate the answer, the application of the remedy must be left to others, to assistants, or the friends of the patient. The former, the Poor-law Commissioners do not furnish, and as regards the latter, nine years' Union practice enables me to give Dr. Macleod an answerviz., they would not do it.

All popular remedies are liable to vicissitudes; to become discarded and obsolete from their indiscriminate use. The late Dr. Cheyne on this subject has the following remarks:"If people bathe indifferently, without advice, without any distinct knowledge of their case, their strength, the proper season, or the time that they ought to remain in the water, unlucky accidents must needs happen, and the parties themselves be subjected to injury and painful disappointment," ("Essay on Gout.") Dr. Strother adds, "It was such indiscretion which at the reviving of the cold bath brought a sort of disgrace upon it; many sought the remedy out of curiosity; some, out of hopes of recovery, ventured into the bath at all hazards, and suffered the penalty of aggravated aftliction or death: it was cried up as a panacea, and no disease could withstand its power. At last, being instructed by many failures, the people abandoned it in disgust. So it follows with popular remedies as with our clothes; they take new shapes according to the dictates of fashion, as if mode was only to be followed, and indications or symptoms to pass for nothing," "Essay on Sickness and Health," pp. 319, 320. London, 1725.) In the British and Foreign Medical Review for October, 1846, there appeared an article on the water cure, wherein it is stated that Priessnitz, in investigating the suitableness of a case for the cure, subjects the patient to an initiatory sprinkling, or witnessed the effect of a cold bath, in order to ascertain the amount of reaction. If this be considerable, he pronounces the case appropriate for his treatment; if not, the patient is recommended to forego all hydropathic intentions.

This, adds the reviewer, is a mode of ascertaining the powers of the constitution quite original, and cannot be said to be unscientific. How far it is original we may learn from Galen, in the third book of his "De Sanitate Fuenda," where he says, if the persons bathing coming out of the water be. come soon high-coloured by friction, it is a sign that they have stayed in a moderate space; but if their colour is long in coming, and returns slowly by friction, they have stayed in too long, wherefore you may always tell the measure of bathing by the skin.

That the great mass of the people at present are insuff- ciently educated to correctly appreciate the wholesome effects of frequent general ablutions, no one attempts to deny. No man of understanding for a moment doubts the benefits to be derived from a good wash-c "à capito ad calcem." From what has been written, it will be perceived that the medical profession have nothing to learn from the cold-water doctors, or their cure, in its present resuscitated form, decorated and blandished forth with all the trumpery and disgusting paraphernalia of quackery. After all, this great fever cure is not so astonishing in its dimensions, when we come to look into its history. According to the poet, it is merely

" a flourish of trumpets,

Cold, applied either by the bath or wet bandages, is but one, and that no new remedy in the materia medica, as its employment for above 2000 years easily proves. Notwithstanding this fact, medical men, in the ages of day-dreams and superstition, never dared to vaunt it up as an universal remedy, no more than they would have ventured to erect universal cathartic institutions, or have sent forth missionaries to propound the absurdities of Perkins, or the mysteries of the royal touch. "Quackery," writes Gideon Harvey, " is the tail end of progression, and bears the same relation to civilization that the goose does to the giblets-sensible men swallow the former, whilst the latter is the dish of ignorant menials and satraps." I am, Sir, yours \&c. John Militgan.

Keighley, September, 1847 .

\section{MEDICAL FEES AT INQUESTS.} To the Editor of TuE LaNCET.

Sin,- Upon learning, for the first time, from your journal, that I had a legal claim against Mr. Payne, the coroner to the City of London, I addressed a letter on the 15 th instant to that gentleman, referring him to your journal, and informing him of my resolve to enforce the payment of my claim of one guinea. Notwithstanding this, he does not grapple with any material point of my letter, but addresses himself solely to your observations.

Mr. Payne commences his letter by complimenting you on "the judicious manner in which you have remarked on Mr. Maybury's 'Complaint against a Coroner." Despite this compliment, $\mathrm{Mr}$. Payne has not acted upon your remarks, as, if he did he would have sent me my fee; for if I understand your observations rightly, they pronounce my claim against him to be legal, if the summons I received be not " a verbal notice," nor an "informal" one, but one as "required by law."

Mr. Payne's letter contains these words, - "I immediately asked why Mr. Maybury had been troubled to attend, and the officer stated he had summoned him by the desire of the deceased's master, who said, that if the coroner did not pay him, he would." This conversation between Mr. Payne and the officer I never heard, and therefore can know nothing about it. From the avowal of Mr. Payne, it appears that his officer, at the suggestion of a deceased person's master, has it in his power to summon any medical man to appear at a coroner's inquest; and when the medical man expects the just remuneration for his lost time, - the consequence of this summons,the coroner coolly tells him to seek it from the deceased's master, at whose bidding the officer issued his mandate. If the master, however, was the responsible party, why did not the summons run thus:- " By virtue of a warrant under the hand and seal of" —_ Farley, Esq., instead of "William Payne, Esq."?

The third paragraph of Mr. Payne's letter contains a misrepresentation. It is not true that Mr. Payne "immediately told me he should not require my evidence." My name was not mentioned at all, directly or indirectly, until after the examination of the medical man, who was the second witness. So mueh for Mr. Payne's words, - "He, however, stayed till the other medical gentleman had been examined." It is equally not correct that I "persisted in urging my claim to give evidence;" because, as I had been summoned, I felt, and do feel, I was entitled to my fee, whether or not my testimony was required.

I must also say that Mr. Payne is in error in ascribing to me an "impression" so foolish as that of "confusing a claim for attendance on the deceased with my claim to be a witness." No such absurd inference is deducible from my published letter, or from my letter to him. What has the payment for attendance upon a deceased to do with the fee which a professional man is undoubtedly entitled to, when summoned, under the hand of a coroner, to attend an inquest? Payment for attendance during life, by the friends or master of the 
deceased, does not surely supersede or liquidate the inquest fee for the loss of time resulting from compliance with a coroner's summons, after the death of a patient.

In respect to Mr. Payne's words, - "He will doubtless be paid by the deceased's master who called him in," I beg to say I doubt it very much. I will be cardid in saying I expect no such payment. I believe no honest medical man, under the circumstances, would imagine he was entitled to any payment from the deceased's master.-I remain, your obedient servant, W. A. MaybURY, M.R.C.S.I. \& L.A.C.L.

Little Tower-street, September, 1847.

\section{ftreứcal \$2ems.}

Apothecaries' IIALL-Names of gentlemen who passed their examination in the science and practice of medicine, and received certificates to practise, on Thursday, September 23rd, 1847 :-Henry Lambden, Burgh, Lincolnshire; John Thomas Campion, Exeter, Devon; John Coghlan IIaverty, Liverpool. Chhursday, Sept. 30th: Horatio Coare Brenchley, Maidstone, Kent; Thomas Hood, London; Joseph Rushforth; Henry Fowler Jenkinson, Doncaster, Yorkshire; Samuel Fowell, Norwich; George Bellasis Marfen, Stafford.

Parisian Hospitals.- From the amnual return just published by order of the French Government, it appears that the legacies and donations made to the indigent and hospitals of Paris, during the year 1846, amonnted to 328,250 francs; of this sum, 260,000 franes was in property, and 68,250 francs in cash.

Quackery. - The Lancet Antr-Quackerx Articues in A MErics.- "About a year ago, there was commenced in THE LArCet a series of articles relating to quackery and the ethical condition of medicine at the present time. These articles display great ability, and have without doubt exercised a very beneficial influence in promoting the cause of legitimate medicine. Some of the more interesting of themsuch as were applicable to our own country-we have from time to time transferred to our columns, and shall do the same with those of the series which hereafter appear." - Philadelphia Medical News, July, 1847.

Apponfments.-Dr. William Henry Elliot, the talented and able exposer of the Mesmeric impostures in Devonshire, has been unanimously elected physician to the Exeter Dispensary.

Medrcal School of TuRkez.-Most of our readers are perhaps acquainted with the existence of a medical school in Turkey-the school of Galata-Serail, at Constantinople. This school is under the immediate patronage of the Sultan, who, with his ministers and other great persons, honours the school with his presence at the close of the scholastic year, when a report is made of the progress of the school, and prizes distributed to industrious students. Those students, also, who are about to take the doctor's degree, produce their theses, and are examined before the Sultan, after which they are admitted to the degree, and take an oath,- the Mussulmen on the Koran, the Christians on the gospels,-for the school is open both to MLhammedans and Christians, and lately also the Jews have resorted to it; these last were especially noticed by his majesty on his recent visit. The report of the school was presented by the chief professor, Dr. Spitzer, which speaks lighly of the progress of the institution, which has now been founded nine years. It stated that 454 students attended, of whom 409 were resident in the school, (314 Mohammedans, ninety-five Greeks, Armenians, Christians, and Jews), and forty-five non-resident. The latter do not enjoy some scholastic advantages and appointments, but a commission in the medical service of the empire is assured to all, and a post of dignity, from that of lieutenant to that of colonel, is attainable by all, without regard to their religion. Those students who at the school examinations cannot rise in the classes, and any whose conduct is improper, are expelled, and sixty were so punished during the past year. Further, it seems that some, after having completed their studies, are not capable of undergoing their final examination for the doctorate, and, consequently, they do not proceed to it, but are sent to one of the military hospitals of Constantinople to perfect their knowledge under the direction of their physicians. They must thus spend two years, when they are allowed to present themselves for examination at the school, which, if they fail to pass, they are never allowed to try again, but are doomed always to be an inferior grade. The school was from the first thrown open to students of all religions, but the Jews have only very recently availed themselves of its advantages. A chair of medical jurisprudence has been founded, and although the law forbids the examination of persons suddenly dead, yet an act has been recently passed, providing for an inquiry into the cause of death by authorized physicians. Up to the present date, druggists were allowed to dispense and practise medicine, but now an order has been given, that no one shall exercise the calling of a druggist without having been previously specially educated for it at the medical school. The military hospitals of the capital are attended by the students, and the Sultana-mother has $\mathrm{ex}$. pressed her desire that the students should have the advantage of attending the hospital at Yemy-Bagtché, the first civil hospital established, founded and endowed by the munificence of that lady. The reputation of the Medical School is extend. ing widely, and the Prince of Servia has already sent eleven pupils to be educated at it for the medical service of his state. This report must be exceedingly gratifying to all the friends of civilization; and, indeed, it reads a lesson to us; for we find, even in Turkey, the country of Europe, in our opinion, the most in the rear of civilization,- that the piblic are not to be exposed to the cheats of every charlatan or pre. tended practitioner, nor to the not-harmless prescriptions of druggists, without adequate medical knowledge; but that the medical profession is to be efficiently protected, and to take a higher stand than it does in the so-called highly civilized country of Great Britain.

Obituanx.-The late Robert Storrs, Esq., of Doncaster, is another medical man added to the list of those who have died of typhus. He was the medical attendant of the $D_{0 n}$ caster Union, and had been exposed during some months to the destructive influence of the "famine fever." A less humane, a less conscientions man might have escaped unscathed. Mr. Storr's assiduity and practical humanity would not allow him to neglect the meanest and poorest of his fellowmen. He has died on the field of duty, and goes to the grave with a character esteemed and respected by thousands. Mr. Storrs was in his forty-seventh year; he practised in Doncaster upwards of twenty-four years, with credit and success. He has left a widow and twelve children to mourn his decease.

\section{CORRESPONDENTS.}

$A$ Wisbeach Subscriber.-.'The extract sent is a true copy from the pares of The LANces, but we, at the time it was published, took it from a local paper, as a point of great interest to the profession. Our correspondent will not regret the change he has made.

M.D., (Brixton.)-The Commissioners of Police appoint the surgeons to the police force. We believe the salary is 200 a year.

W. King.-The only advice we can give is to avoid quacks, and to consult any respectable physician or surgeon. Avoid the advertising crew. This advice also applies to "Powerless" and " Discipulus."

J. V.L.-Physiology could not properly be termed the institutes of medicine-at least, this is not the mearing of the term in the English schools. A Student, (University College.)-The Lying-in Hospital, Queen-street, Golden-square, offers excellent opportunities for the study of practical mid. wifery.

H. H.-The Registration Bill would of itself, as a whole, render such a clanse as that proposed by our correspondent unnecessary.

Putney Inquest. - We had prepared some further strictures on the conduct of the parties concerned in this transaction, but are obliged to defer them till our next.

Mr. Frederick Leonidas Collyer writes to say, that he is at law with his father, Dr. Collyer-that he is on no more in:imate terms with him than our corrcspondent of last week. Our correspondent's error must bare arisen from the distribution of eirculars in the name of Dr. Collyer, asking the public to purchase his orange quinine wine at the shop in question.

$M r$. Furmer (Putney) writes to say, that the copies of the medical jurot's letter, circulated in Putney as a handbill, was obtained by him (Mr. Farmer) from the Morming Post office on the day of the publication of the letter, "unknown and unsanctioned by" the medical juror.

Scotus.- We shall publish the scotch regulations next week. The ex. tract from the prospectus is perfectly correct.

Mr. Robert Allen, (Staff surgeon, Mauritius.) - We have received from this gentleman the details of a case in which hydrophobia was treated by the inhalation of ether. The case is, we believe, the first of the kind, and we shall, of course, publish it.

ErRATUM : Mr. Leach's address should have been 34, Gloucester-street, Queen-square; or 2, Savoy-street.

Communications have been received from-Mr. Micklethwaite, (Sheffield;) Dr. Turkbull, (Liverpool;) Mr. W. A. Maybury; Dr. Radford, (Man. chester;) A Wisbeach Subscriber; Mr. W. King; Scotus; An Englishman; A Poor.law Medical Officer; Dr. Robert Paton, (Wetherby;) Mr. Ma. cauley, (Leicester;) J. V. L. ; Dr. Ogilvie, (Aberdeen ;) Mr. J. Scott, (Edinburgh; Mr. Robert Allen, (Staff-surgeon, Mauritius;) Mr. W. J. Clarke, (Huddersfield ;) Discipuius; H. H.; Powerless; A Student, (University College;) M.D., (Brixton;) Mr. Farmer, (Putney ;) Dr. Arthur Wilson; Mir. F. L. Collyer; Censor; \&c. 